PENELITIAN PENINGKATAN KAPASITAS/PEMBINAAN PENGABDIAN KEPADA MASYARAKAT BERBASIS PRODI

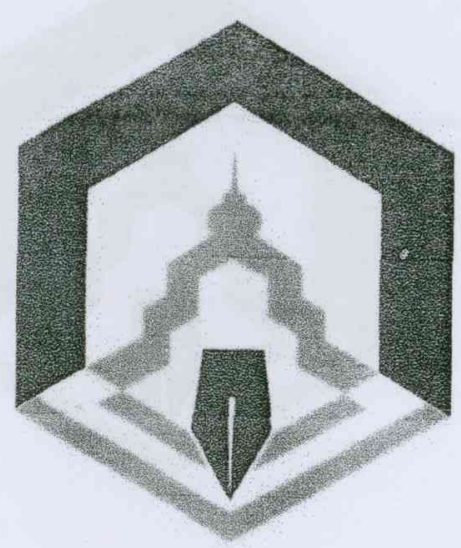

PELATIHAN PENYELENGGARAAN JENAZAH MUSLIM DI SMA NEGERI 4 KOTA PALOPO

oleh:

HISBULLAH, S.Pd., M.Pd.

ID : 20007800108407

PROGRAM STUDI PENDIDIKAN AGAMA ISLAM

FAKULTAS TARBIYAH DAN ILMU KEGURUAN

INSTITUT AGAMA ISLAM NEGERI (IAIN) PALOPO 


\title{
PELATIHAN PENYELENGGARAAN JENAZAH MUSLIM \\ DI SMA NEGERI 4 KOTA PALOPO
}

\author{
Oleh: \\ Hisbullah, S.Pd., M.Pd. \\ (Dosen Program Studi Pendidikan Agama Islam)
}

\begin{abstract}
Abstrak
dunia adalah melaksanakan peny muslim jika ada saudara muslim yang lain meninggal dilakukan oleh muslim yang masih garaan jenazah si mayit. Kewajiban yang harus memandikannya, mengkafaninya, mengsholatka dalam penyelenggaraan jenazah adalah

Merujuk pada kewajiban tersebut matkannya, dan menguburkannya.

mengetahui pelenggaraan jenazah tersebut diharapkan setiap muslim memahami dan manusia, yang pada umumnya merupakan jenjasia SMA merupakan awal masa dewasa dapat melanjutkan pendidikan ke jenjang perguruandidikan terakhir bagi siswa yang tidak bergut akan langsung bergabung dengan masyaraka. Setelah taman SMA maka siswa bergabung dalam pelaksanaan-pelaksanaan ritumarakat sosial yang memaksa untuk

SMA Negeri 4 Kota Paloparakat.

beragama Islam, yang diharapkan mampuan salah satu sekolah umum yang mayoritas jenazah. Tujuannya adalah minimal mereka dami dan memahami penyelenggaraan penyelenggaraan jenazah lingkungan keluarganya dapat ambil bagian dalam prosesi

Pelatihan penyelenggaraan

besar bagi pengembangan ilmuzah di SMA Negeri 4 Kota Palopo memberi kontribusi jenazah. Guru dan siswa antuasias dan Islam, terutama pengetahuan penyelenggaraan karena sebelunya belum pernah dilaksaras senang dengan pelatihan yang diberikan, selama ini materi penyelenggaraan jenazah di sekolah. Guru PAI mengutarakan bahwa peraga yang kurang memadai, sehingga selanya bersifat teori dikarenakan waktu dan alat

Pelatihan penyelenggaraan jenazah diawa siswa hanya memahami teorinya.

fiqhi, dimana dalam penyajian materinya diawali dengan pemberian materi oleh dosen ahli Tanya jawab yang berkaitan dengan materi peserta diberi kesempatan untuk melakukan dilanjutkan dengan praktek penyelenggar yang diberikan. Setelah pemberian materi,maka mengkafani jenazah, mensholatkan jenazah, hin jenazah, mulai dari memandikai jenazah,

Akan tetapi, dikarenakan

menyentuh kepada seluruh peserta. jembatan dalam memantapkan per. Namun diharapkan pada guru PAI akan menjadi jenazah yang belum dipahami.
\end{abstract}

Keyword: Pelatihan dan Pendampingan, Masyarakat Sekolah, Penyelenggaraan jenazah 


\section{BAB I}

\section{PENDAHULUAN}

\section{A. Latar Belakang}

Salah satu tuntunan agama Islam yang wajib disegerakan adalah melaksanakan/ menyelenggarakan Jenazah bagi sesama muslim. Bahkan jika seorang muslim meninggal maka saudara semuslim wajib mengurusinya sampai memakamkannya. Dan apabila si mayit sampai terlantar maka semua orang yang berada di sekitar mayit ikut berdosa.

Sesuai ketentuan Agama Islam, penyelenggaraan jenazah dilakukan melalui suatu prosedur tertentu. Prosedur dimaksud merupakan persyaratan yang harus ditempuh apabila salah seorang umat Islam meninggal dunia. Dalam hukum Islam ada empat kewajiban yang harus diperlakukan pada seseorang yang telah meninggal dunia, yaitu: (i) memandikan, (ii) mengafani, (iii) menyalatkan, dan (iv) mengubur jenazah tersebut. ${ }^{1}$ Dengan demikian pelatihan penyelenggaa ranijenazah menjadi sangat penting dilakukan.

Alasan yang sangat mendasar adalah yang mengelenggarakan jenazah biasanya hanya dibebankan kepada pengurus masjid yang nota benenya sudah berumur lanjut usia. Sehingga diharapkan dengan penelitian pengabdian ini, terjadi perpanjangan tangan antara kaum tua dengan kaum muda, terkhusus para siswa SMA di Kota Palopo dapat mengetahui dan mampu melaksanakan penyelenggaraan jenazah.

Kurangnya pemaham masyarakat tentang penyelenggaraan jenazah terutama dikalangan anak muda menjadi masalah yang sangat besar di kalangan masyarakat Dengan dasar rasa peduli terhadap sesama, rasa peduli ini dapat kita tumbuhkan atau dipraktekkan dalam kegiatan pembelajaran melalui kegiatan melayani, dalam hal ini melayani kebutuhan pemahaman penyelenggaraan jenazah yang dibutuhkan oleh masyarakat sekolah. Masyarakat sekolah yang dimaksudkan disini adalah guru dan siswa. Sedangkan keterbatasan keterampilan dalam penyelenggaraan jenazah diminimalkan dengan memberikan layanan dan bimbingan atau pelatihan untuk guru dan siswa dalam penyelenggaraan jenazah

Kegiatan ini merupakan suatu pembelajaran yang menggunakan pendekatan ilmu dengan cara memberikan keterampilan untuk melaksanakan tugas dalam

\footnotetext{
Misran Rahman, Implementasi dan

Bulota Kec. Telaga Kab. Gorontalo,
} 


\section{BAB II}

\section{TINJAUAN PUSTAKA}

\section{A. Konsep Pemberdayaan}

Menurut Depdiknas (2003), secara bahasa pemberdayaan adalah proses, cara, perbuatan membuat berdaya, yaitu kemampuan untuk melakukan sesuatu atau kemampuan bertindak yang berupa akal, ikhtiar atau upaya. Selanjutnya menurut Mubarak (2010) pemberdayaan masyarakat dapat diartikan sebagai upaya untuk memulihkan atau meningkatkan kemampuan suatu komunitas untuk mampu berbuat sesuai dengan harkat dan martabat mereka dalam melaksanakan hak-hak dan tanggung jawabnya selaku anggota masyarakat.

Ide utama pemberdayaan bersentuhan dengan konsep mengenai modal sosial dan kekuasaan. Kekuasaan dikaitkan dengan kemampuan individu untuk membuat individu melakukan apa yang diinginkan, terlepas dari keinginan dan minat mereka.

Pemberdayaan adalah sebuah proses dan tujuan. Sebagai proses, pemberdayaan adalah serangkaian kegiatan dalam hal ini pelatihan dan pendampingan untuk memperkuat keterampilan pada kelompok tertentu dalam masyarakat. Sebagai tujuan, maka pemberdayaan merujuk pada keadaan atau hasil yang ingin dicapai oleh sebuah perubahan sosial.

\section{B. Masyarakat Sekolah}

Menurut Koentjaraningrat (2009), masyarakat adalah kesatuan hidup manusia yang berinteraksi menurut suatu sistem adat istiadat tertentu yang bersifat kontinyu dan yang terikat oleh suatu rasa identitas bersama. Masyarakat menurut KBBI adalah sejumlah manusia dalam arti seluas-luasnya dan terikat oleh suatu kebudayaan yang mereka anggap sama. Sedangkan sekolah adalah bangunan atau lembaga untuk belajar dan mengajar serta tempat menerima dan memberi pelajaran. Menurut Desbay (2015) masyarakat sekolah adalah kelompok sekunder lengkapdengan in-group dan out-group feelingnya. Sebagai kelompok sekunder (kelompok yang dibentuk dengan sengaja) masyarakat sekolah adalah organisasi formal lengkap dengan ciri- ciri adanya peraturan dan prosedur yang ketat, hirarki jabatan/pimpinan dengan hak dan kewajibannya masing-masing, pelaksanaan administrasi secara profesional, mekanisme 
"mohonlah pengampunan bagi saudaramu dan mintakanlah ketegaran untuknva. karena sesungguhnya sekarang ia sedang ditanya." (H.R Abu Dawud)

\section{BAB III \\ METODE PENELITIAN}

\section{A. Model Kegiatan}

Kegiatan pengabdian masyarakat berbasis prodi yang dilaksanakan program studi pendidikan agama Islam ini berbentuk seminar yang dilakukan dalam satu kali kegiatan. Metode yang digunakan adalah tanya jawab dan demonstrasi. Metode tanya jawab dilakukan pasa sesi pertama, dimana setelah pemaparan materi oleh narasumber akan dilanjutkan dengan tanya jawab antara peserta dengan narasumber. Metode demonstrasi digunakan pada kegiatan praktikum penyelenggaraan jenazah yang dilakukan pada sesi kedua, kegiatan tersebut dilakukan setelah kegaiatan tanya jawab pada sesi pertama selesai.

\section{B. Strategi yang Dipergunakan}

Adapun strategi yang kami gunakan, yaitu:

1. Tahap persiapan, memilih mahasiswa yang akan dilibatkan dalam pengabdian ini, mengunjungi sekolah-sekolah yang ada di Kota Palopo untuk observasi pemanfaatan alat peraga di sekolah tersebut, menyusun rencana berdasarkan kebutuhan yang ada di sekolah- sekolah, dengan mengorganisir masalah-masalah pokok yang menjadi pertimbangan mahasiswa Pendidikan Agama Islam dalam memberikan pelayanan kepada guru dan siswa serta menyusun rencana pelatihan .

2. Tahap melayani, mengimplementasikan rencana kegiatan dengan memberikan pelatihan langsung dan pendampingan kepada guru dan siswa, sehingga guru dan siswa memiliki keterampilan dalam penyelenggaraan jenazah. Pelatihan akan dilaksanakan dalam waktu 1 hari, proses pelatihan ini direncanakan terlaksana pada minggu ke 3 Juni 2018. Pelatihan ini dilakukan dalam 2 tahap yaitu:

a) Tahap Pemberian Materi

Pemberian materi peneyelenggaraan jenazah muslim diselenggarakan pada tahap pertama, dimana dosen pengampu mata kuliah Fiqhi akan menjelaskan 
BAB IV

\section{HASIL PENELITIAN}

\section{A. Pelaksanaan Kegiatan}

1. Persiapan Kegiatan Pengabdian

Sebelum kegiatan pengabdian masayarakat dilakukan peneliti melakukan pesiapan-pesrsiaapan sebagai berikut:

a. Melakukan penelusuran studi pustaka tentang sistematika penyelenggaraan jenazah muslim.

b. Mengadakan observasi pada tempat pelaksanaan pengabdian.

c. Menentukan tanggal pelaksanaan serta jumlah peserta yang akan mengikuti kegiatan pengabdian.

d. Menyusun susunan acara dan materi yang akan disajikan dalam pengabdian.

2. Pelaksanaan Kegiatan Pengabdian

Kegaiatan pengabdian pelatihan penyelenggaraan jenazah dilaksanakan pada hari Sabtu 15 September 2018 pada pukul 13.00 16.00 Wita, dengan dihadiri sebanyak 70 peserta yang terdiri dari 63 siswa dan 7 guru SMA Negeri 4 Kota Palopo. Kegiatan terbagi atas dua tahapan, yaitu tahap pertama penyampaian materi yang dirangkaikan dengan Tanya jawab tentang penyelenggaraan jenazah, selanjutnya pada tahap kedua dilanjutkan dengan kegiatan praktikum penyelenggaraan jenazah.

\section{B. Hasil Kegiatan}

Berdasarkan wawancara dan hasil pengamatan selama kegiatan berlangsung, kegiatan pengabdian ini memberikan hasil sebagai berikut:

1. Meningkatkan pengetahuan serta pemahaman peserta baik secara teoritis maupun praktikum tentang tata cara penyelenggaraan jenazah.

2. Memberi kejelasan tentang beberapa pemahaman yang keliru di masyarakat tentang prosesi penyelenggaraan jenazah yang tidak sesuai dengan syariat Islam. 


\section{BAB V}

\section{PENUTUP}

\section{A. Kesimpulan}

Partisipasi yang ditunjukkan oleh peserta pelatihan penyelenggaraan jenazah memberikan bukti bahwa kegiatan pengabdian ini sangat penting dan dibutuhkan oleh masyarakat Muslim terutama warga sekolah.

Sikap partisipasi yang ditunjukkan oleh guru dan siswa menggambarkan bahwa pelatihan penyelenggaraan jenazah merupakan kebutuhan bagi guru dan siswa sebagai seorang muslim yang berkewajiban untuk turut serta dalam penyelenggaraan jenazah.

Masyarakat sekolah merupakan wadah dimana masyarakat umum bergantung kepada hasil pendidikan di sekolah, baik pendidikan umum maupun pendidikan agama. Sehingga dengan adanya pelatihan ini menjadi bekal bagi guru, terutama bagi siswa untuk turut ambil bagian dalam penyelenggaraan jenazah di masyarakat.

B. Saran

Penelitian ini diharapkan dapat disosialisasikan sampai ke pelosok daerah, sehingga masyarakat muslim dapat mengetahui dan memahami penyelenggaraan jenazah, tanpa harus bergantung pada pengurus masjid. 